Article

\title{
In Vivo Cytogenotoxicity of Electronic Waste Leachate from Iloabuchi Electronic Market, Diobu, Rivers State, Nigeria on Allium Cepa
}

\author{
Bolaji Babatunde * and Felicity Anabuike \\ Department of Animal and Environmental Biology, Faculty of Biological Sciences, \\ College of Natural and Applied Sciences, University of Port Harcourt, P.M.B. 5323, Choba Port \\ Harcourt, Rivers State, Nigeria
}

* Author to whom correspondence should be addressed; E-Mail: bolaji.babatunde@ uniport.edu.ng.

Academic Editor: Andreas Manz

Received: 6 May 2015 / Accepted: 29 May 2015 / Published: 3 June 2015

\begin{abstract}
The human and environmental impact of electronic waste is increasing due to its careless disposal. Cytogenotoxicity of electronic waste from Iloabuchi electronic market, Diobu, Rivers State was investigated using the Allium cepa bioassay comprised of the root elongation and chromosome aberration tests. Leachate samples of e-waste analysed were above maximum permissible limits. Toxicity to root growth of A. cepa was evaluated at concentrations of $5 \%, 10 \%, 25 \%, 50 \%$, and $100 \%$ showed root growth inhibition at all concentrations of the samples compared to the control and root growth inhibition was concentration dependent. An effective concentration $\left(\mathrm{EC}_{50}\right)$ at which root growth amounted to $50 \%$ of control for the sample was $37.5 \%$. Various morphological defects of the onion roots were observed including short, crochet roots, C-tumor roots and severe toxic effects where no growth was observed. In the in vivo genotoxity assay, all samples lowered the frequency of mitotic cells in the meristematic region of the roots at statistically significant levels $(P<0.05)$ compared to the control and mitotic inhibition was also concentration dependent. There was significant induction of aberrations at all concentrations tested compared to control. The high metal content of the e-waste leachate may be responsible for observed cytotoxicity in A. cepa roots cells.
\end{abstract}

Keywords: genotoxicity; electronic waste; Allium cepa; chromosomal aberration 


\section{Introduction}

Waste electrical and electronic equipment (WEEE) popularly known as e-waste has fast become one of the major sources of contamination to the environment and humans. The WEEE typically consist of discarded TV sets, refrigerators, microwave ovens, mobile phones, computers and accessories, recordable electronics such as DVDs, VCRs, tape recorders, radios and other audio visual equipment. These discarded electrical and electronic goods contain a range of toxic materials such as furans, dioxins, polycyclic aromatic hydrocarbons (PAHs), polyhalogenated aromatic hydrocarbons (PHAHs), hydrogen chloride and trace metals. These toxic materials require special handling prior to disposal [1,2] and can become difficult and expensive to recycle safely for profit [3].

Computing is driving the generation of e-waste. According to [4], information and telecommunications technology (ICT) and computer internet networking has penetrated nearly every aspect of modern life, and is positively affecting human life even in the most remote areas of the developing countries. Debate on environmental, health and social problems associated with the uncontrolled dumping and inappropriate recycling of e-waste has already reached the mainstream of policy-makers in developed as well as developing countries. However, most of the developing countries have not yet been able to enforce national policies and legislations for managing e-waste. Furthermore, lack of technology and skills, and unexplored business and financing opportunities, coupled with an exponential growth in the use of electric and electronic equipment in the developing countries, have led to severe challenges in terms of managing e-waste in a proper manner [5]. As e-waste entails several toxic and hazardous substances, its improper processing, recycling and disposal leads to severe health hazards, environmental pollution and social problems, not only for the people involved directly in e-waste related activities, but also for the local communities and the society as a whole.

Developed countries have conventions, directives, and laws to regulate their disposal, most based on extended producer responsibility (EPR). Manufacturers take back items collected by retailers and local governments for safe destruction or recovery of materials. Compliance, however, is difficult to assure, and frequently runs against economic incentives. The expense of proper disposal leads to the shipment of large amounts of e-waste to China, India, Pakistan, Nigeria, and other developing countries. Shipments are often through middlemen, and under tariff classifications that make quantities difficult to assess. Therefore, despite the intent of regulations and hazardous waste laws, most e-waste is treated as general refuse, or crudely processed, often by burning or acid baths, with recovery of only a few materials of value [2]. In the developing world such as Nigeria, e-waste is simply dumped in municipal solid waste streams without considerations for its potential harm to the environment and human health [6].

According to [1], effective reprocessing technology, which recovers the valuable materials with minimal environmental impact, is expensive, so most e-waste is disposed in landfills in the developed world with strict guidelines. Consequently, although illegal under the Basel Convention, rich countries export an unknown quantity of e-waste to poor countries, where inadequate recycling techniques include burning and dissolution in strong acids with few measures to protect human health and the environment is practiced. Such reprocessing initially results in extreme localised contamination followed by migration of the contaminants into receiving waters and food chains where they can become very dangerous due to biomagnification at higher trophic levels [6]. E-waste is chemically and physically distinct from other 
forms of municipal or industrial waste; it contains both valuable and hazardous materials that require special handling and recycling methods to avoid environmental contamination and detrimental effects on human health. Recycling can recover reusable components and base materials, especially $\mathrm{Cu}$ and precious metals. However, due to lack of facilities, high labour costs, and tough environmental regulations, rich countries tend not to recycle e-waste. Instead, it is either put into landfills, or exported from rich countries to poor countries, where it may be recycled using primitive techniques and little regard for worker safety or environmental protection. Others work to strip insulation from all wiring in an attempt to salvage tiny amounts of copper wire. Uncontrolled burning, disassembly, and disposal causes a variety of environmental problems such as groundwater contamination, atmospheric pollution, or even water pollution either by immediate discharge or due to surface runoff (especially near coastal areas), as well as health problems including occupational safety and health effects among those directly and indirectly involved, due to the methods of processing the waste. The soils and plants were shown to be contaminated with lead, cadmium, chromium, zinc, copper, arsenic, PAHs, PBDEs and PCBs.

There is a paucity of information on the genotoxicity of e-waste, although a few reports exist such as Alabi and Bakare [7] and Bakare et al. [8], which reported the cytogenotoxicity and mutagenicity of ewaste in plant and animal systems. Informal e-waste dumpsites may contain toxic trace metals and organic contaminants which may be concentrated in surface and groundwater supplies around these ewaste dumpsites through lateral and vertical transfer of contaminants. Such contaminants may become bio-accumulated in aquatic organisms, become biomagnified in fish that are at the top of the aquatic food chain, and can ultimately affect humans who feed on such fishes. It has therefore become imperative to monitor and evaluate the potential cytogenotoxic effect of e-waste using Allium cepa assay, a quick, efficient, simple but sensitive cytotological bioassay. Environmental pollution has been assessed by the in vivo onion (Allium cepa) root tip cell test which is known to give similar result to the in vitro animal cytotoxicity test $[7,8]$. Allium cepa test has also been used by many authors to evaluate cytotoxicity and genotoxicity of industrial leachates $[9,10]$, and its results are widely accepted as reconnaissance for toxicity testing in biological systems.

In this study, we investigated the cytogenotoxicity potential of e-waste from a major electronic market in Rivers State, Nigeria using a higher plant monitoring system, the Allium cepa assays.

\section{Materials and Methods}

\subsection{Study Area}

The study site, Iloabuchi Market, Port Harcourt, is located in Obio-Akpor LGA of Rivers State (Latitude 04 ${ }^{\circ} 47^{\prime} 13.5^{\prime \prime} \mathrm{N}$ and Longitude 006 $59^{\prime} 28.3^{\prime \prime E}$ ), Nigeria (Figure 1). The market is the largest in Port Harcourt where sales of fairly used and new electric and electronic goods are traded it is surrounded by residential quarters. Within the market, there are many illegal dumpsites where obsolete electronics are usually dumped, dismantled for crude recycling, and the remaining scraps burnt to reduce waste volume [11]. 


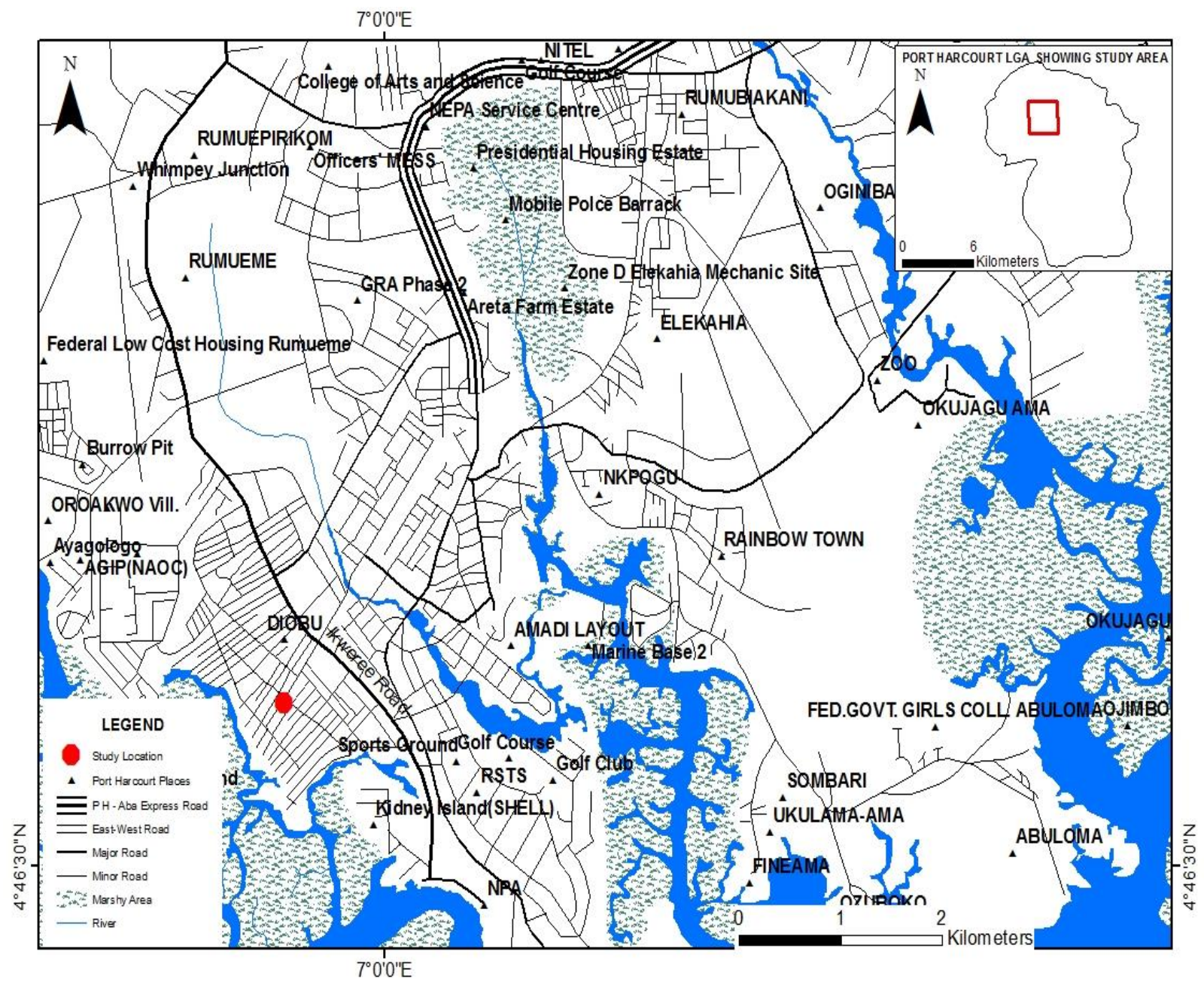

Figure 1. E-waste dumpsite Iloabuchi electronics market, Port Harcourt, Rivers State, Nigeria.

\subsection{Test Leachate}

Electronic waste was obtained from the waste dump of a large electronic market in Iloabuchi in ObiaAkpor LGA, Rivers State. The diodes from the electronic waste were leached with hot water and poured into a 4 liter container with screw cap and stored at $4{ }^{\circ} \mathrm{C}$ for one week until it was analyzed for physicochemical properties and used for the bioassay.

\subsection{Determination of Physical and Chemical Parameters}

The leachate was analyzed for a number of standard physico-chemical properties, including chemical oxygen demand (COD), total dissolved solids (TDS), alkalinity, biochemical oxygen demand (BOD), chlorides, nitrates, ammonia and phosphates, according to methods described by [12]. Eight heavy metals, namely lead $(\mathrm{Pb})$, cadmium $(\mathrm{Cd})$, copper $(\mathrm{Cu})$, chromium $(\mathrm{Cr})$, iron $(\mathrm{Fe})$, zinc $(\mathrm{Zn})$, and nickel (Ni) were analyzed in the leachates sample according to standard analytical methods $[12,13]$. 


\section{Experiment}

\subsection{Allium cepa Assay}

The biological materials were equal-sized onion (Allium cepa-2n $=16$ ) bulbs of the purple variety (average size 15-22 mm diameter) purchased locally at Choaba market, Port Harcourt City, Rivers State. They were sun-dried for more than two weeks before start of experiment [14]. The Allium test for macroscopic as well as microscopic evaluations was done as described by Fiskesjo [15] and [10]. The outer scales of the onion bulbs and brownish bottom plate were removed, leaving the ring of root primordial intact. The peeled bulbs were put into fresh tap water during the cleaning procedure to protect the primordial from drying.

\subsection{Toxicity of Samples to Onion Root Growth}

The onion bulbs were exposed directly in 5, 10, 25, 50 and 100\% concentrations (v/v, leachate/tap water) of the test sample leachate. Twelve onion bulbs were cultivated in each concentration of the sample, out of which the best ten with good root growth were selected for analysis of root growth inhibition. Tap water was used as a negative control and similar planting procedure repeated. The experiment was set up in the dark at $25 \pm 1{ }^{\circ} \mathrm{C}$ for $72 \mathrm{~h}$. Test liquids were refreshed daily. Photographs of test materials were taken with canon Digital Camera and special note was taken of change of colour of root tip and morphological changes. The $\mathrm{EC}_{50}$ which is effective concentration at which root growth amounts to $50 \%$ of the control was interpolated for each test sample from the plot of root lengths against the log of leachate concentrations. The effects of samples on the morphology of growing roots were also examined and photographs taken.

\subsection{Chromosomal Aberrations in A. cepa}

For this evaluation, root tips of two most poorly grown bulbs of a series of each concentration were cut After $48 \mathrm{~h}$ and fixed in freshly prepared ethanol:glacial acetic acid (3:1, v/v) and hydrolyzed with a solution of $1 \mathrm{~N} \mathrm{HCl}$ at $65{ }^{\circ} \mathrm{C}$ for 3 min during slides preparation. Two hydrolysed root tips were squashed on each slide, teased and stained with acetocarmine for 10 minutes. Excess stain was removed with a filter paper and a cover slip carefully lowered on the preparation to exclude air bubbles. The cover slip was sealed on the slides with finger nail polish as suggested by [10]. Six slides were prepared for each concentration out of which four were used for microscopic observation under oil immersion at $\times 1000$ magnification with Nikon Microscope (Model PC1733 fitted with canon full HD Digital Camera 16.1 megapixels). Four thousand cells were observed for each concentration.

\subsection{Statistical Analysis}

According to [16], at a minimum, the means with 95\% confidence limits and standard deviations for each of the quantitative sets of data should be presented. Root growth in percentage of control was computed and percentage root growth inhibition calculated using a Microsoft Excel spreadsheet. The mitotic index was determined by counting the number of dividing cells per 1000 cells on a slide and the proportion determined. The frequency of aberrant cells per 1000 cells was examined at metaphase and 
anaphase. Microsoft Excel software was used to compute correlation coefficients for the relationship between root growth inhibition and mitotic inhibition to determine the extent of relationship between macroscopic and microscopic parameters in the Allium cepa test. Student t-test was used to compare the means of root growth inhibition in treated and control at $P<0.05$ probability level.

\section{Results}

\subsection{Physico-Chemical Characteristics}

The physical and chemical characteristics of the e-waste leachate used in this study are shown in Table 1. The values obtained for tap water compared well with the suggested and maximum allowable levels for drinking water by the federal environmental protection agency $[13,17,18]$. The values obtained for e-waste leachate samples were much higher for most of the parameters compared to standard guidelines and maximum permissible limits for industrial discharge into inland waters by [17]. The concentrations of toxic metals such as $\mathrm{Cd}, \mathrm{Cr}$, and $\mathrm{Pb}$ in e-waste leachate were $0.56,0.31$, and $1.35 \mathrm{mg} / \mathrm{L}$, respectively, and these values are well above the stipulated maximum limits by [17]. The leachate was turbid with an offensive odour and slightly acidic with pH value of 6.17.

Table 1. Physical and chemical characteristics of the electronic waste leachates assessed for genotoxicity.

\begin{tabular}{llllll}
\hline Parameter & Unit & E-waste & Tap water & FEPA & USEPA \\
\hline PH & - & 6.17 & 7.5 & 6.9 & $6.5-8.5$ \\
colour & - & Milky white & Colourless & - & - \\
odour & - & unpleasant & Odourless & - & - \\
SALINITY & - & 120 & 1.4 & - & - \\
TEMPERATURE & ${ }^{\circ} \mathrm{C}$ & 29.2 & 26.1 & $<40{ }^{\circ} \mathrm{C}$ & $<40{ }^{\circ} \mathrm{C}$ \\
Dissolved oxygen & $\mathrm{mg} / \mathrm{L}$ & 3.96 & & - & - \\
TURBIDITY & $\mathrm{FTU}$ & 90.3 & 0 & 10 & 10 \\
Total dissolved solid & $\mathrm{mg} / \mathrm{L}$ & 175 & 78 & 2000 & 500 \\
Lead & $\mathrm{mg} / \mathrm{L}$ & 1.35 & 0.04 & 0.01 & 0.015 \\
Cadmium & $\mathrm{mg} / \mathrm{L}$ & 0.56 & 0.01 & 0.05 & 0.05 \\
Chromium & $\mathrm{mg} / \mathrm{L}$ & 0.31 & 0.5 & 0.05 & 0.05 \\
Copper & $\mathrm{mg} / \mathrm{L}$ & 5.27 & 1.4 & 0.30 & 1.00 \\
Iron & $\mathrm{mg} / \mathrm{L}$ & 1.53 & 0.05 & 0.05 & 0.30 \\
Nickel & $\mathrm{mg} / \mathrm{L}$ & 10.22 & 1.3 & - & - \\
Zinc & $\mathrm{mg} / \mathrm{L}$ & 6.12 & 1.3 & 1.00 & 1.00 \\
\hline
\end{tabular}

All values were in $\mathrm{mg} / \mathrm{L}$ except temperature, which is in ${ }^{\circ} \mathrm{C}$, and turbidity in FTU.

\subsection{Toxicity of the Leachate to Root Growth in A. cepa}

The degree of toxicity of the tested samples to A. cepa root was assessed by means of root length values measured $72 \mathrm{~h}$ after exposure to the test medium. Root growth was assumed to be maximum $(100 \%)$ in controls. Table 2 shows the effect of e-waste simulated leachate sample on the root growth of A. cepa. Root growth in percentage of control decrease with increased concentration of samples. The 
highest percentage root growth of $77.1 \%$ was recorded for $5 \%$ concentration corresponding to $22.9 \%$ root growth inhibition. While the least percentage root growth of $19.7 \%$ corresponding to root growth inhibition of $80.3 \%$ was obtained at $100 \%$, which was the highest concentration tested in Table 2 and Figure 3. Inhibition of root growth by e-waste leachate was strictly concentration-dependent as illustrated in Figure 3. The curve shows a linear relationship of consistent decrease in $\%$ root growth with increase concentration, and the root growth inhibition varied statistically at $P<0.05$ probability level increasing in statistical significance with increase concentration Table 2. From the graph, 50\% effective concentration ( $\mathrm{EC}_{50}$ ) was deduced to be $37.5 \%$. This corresponds to the concentration of e-waste leachate at which root growth inhibition amounts to $50 \%$ of the control.

Exposure of Allium cepa roots to the leachate at 0,5, and $10 \%$ did not cause any change in colour of roots; however, at higher concentrations of 25 and $50 \%$, roots were pale and at $100 \%$, the roots were dark brown/black in colour. The root malformations observed at these leachate concentrations were twists, 'crotchet hooks' (root tips bent upwards resembling hooks) and c-tumor (abnormalities appearing as swellings of the root tips) (Figure 2).
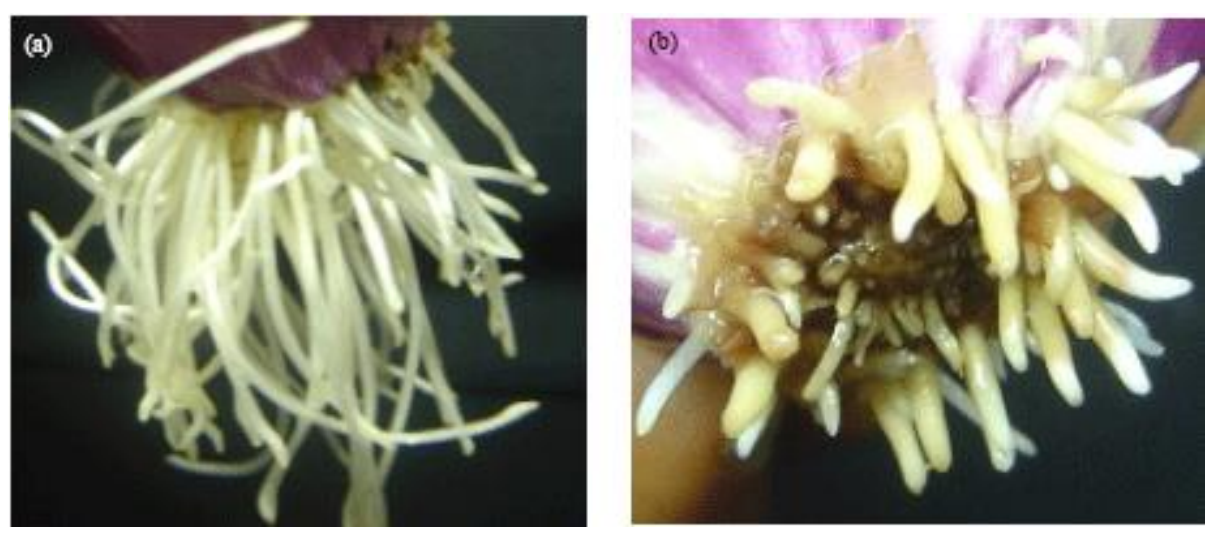

Figure 2. Macroscopic effects on Allium cepa roots exposed to E-waste leachate. (a) Crochet roots (10\% of e-waste leachate and (b) C-tumor roots (50\%-100\% e-waste leachate).

Table 2. Mean Root length of Allium cepa and \% root growth inhibition at different concentrations of electronic leachate.

\begin{tabular}{ccccc}
\hline Concentration (\%) & Mean Length $\pm \mathbf{S E}$ & $\begin{array}{c}\text { Root growth } \\
\text { inhibition }(\boldsymbol{\%})\end{array}$ & $\boldsymbol{P}<\mathbf{0 . 0 5}$ & $\mathbf{9 5 \%} \mathbf{C L}$ \\
\hline 0 & $2.71 \pm 0.11$ & - & & 0.6 \\
5 & $2.09 \pm 0.17$ & 22.9 & $0.0498^{*}$ & 0.34 \\
10 & $1.94 \pm 0.20$ & 28.7 & $0.0346 *$ & 0.23 \\
25 & $1.71 \pm 0.20$ & 36.9 & $0.0139 * *$ & 0.33 \\
50 & $1.01 \pm 0.06$ & 62.8 & $0.0005 * * *$ & 0.4 \\
100 & $0.53 \pm 0.10$ & 80.3 & $0.0002 * * *$ & 0.31 \\
$\mathrm{EC}_{50}=37.5 \%$ & & & &
\end{tabular}




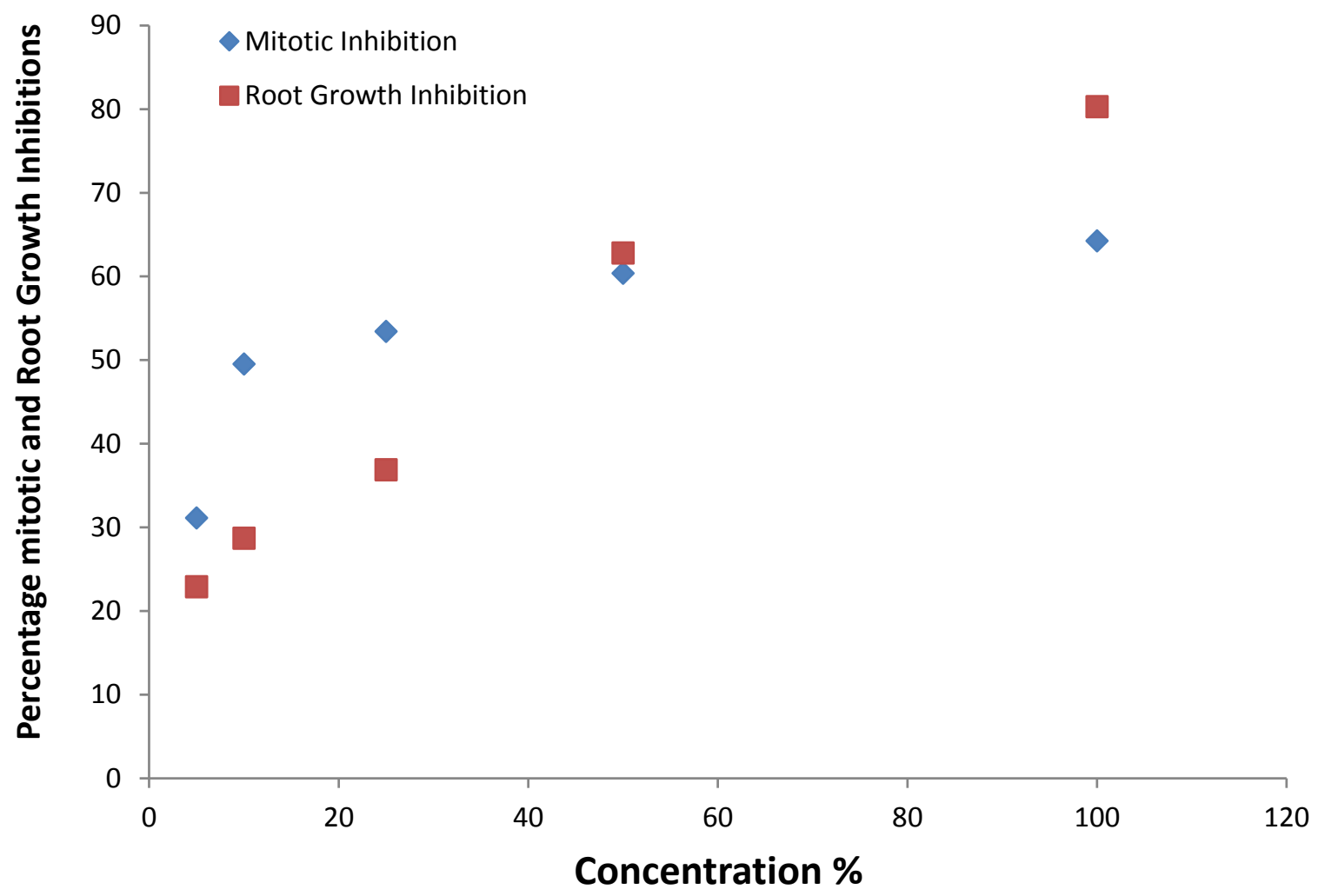

Figure 3. Relationship between percentage mitotic and root growth inhibitions at various concentrations of e-waste leachate.

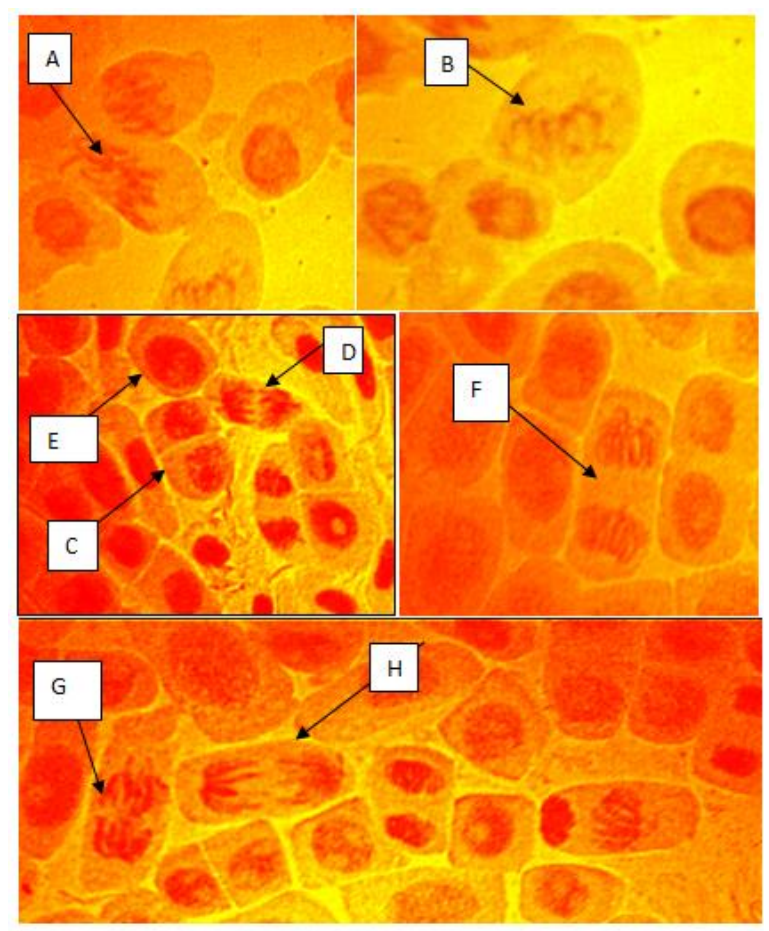

Figure 4. (A-H) Chromosomal aberrations observed in root tip cells of Allium cepa exposed to electronic waste (A) disturbed spindle and fragmentation, (B) sticky chromosome; (C) normal prophase; (D) normal anaphase; (E) interphase; (F) normal telophase; (G) chromosome bridge; (H) laggard chromosome. 
Table 3. Chromosomal aberrations in Allium cepa cells treated with different concentrations of e-waste leachate.

\begin{tabular}{|c|c|c|c|c|c|c|c|c|c|c|}
\hline \multirow[t]{2}{*}{$\begin{array}{l}\text { Concentration } \\
(\%)\end{array}$} & \multicolumn{9}{|c|}{ No. of classified cells } & \multirow[t]{2}{*}{$\begin{array}{l}\text { Total } \\
\text { aberration }\end{array}$} \\
\hline & $\begin{array}{l}\text { Cells at } \\
\text { anaphase }\end{array}$ & $\begin{array}{l}\text { Cells at } \\
\text { prophase }\end{array}$ & $\begin{array}{l}\text { Stiky } \\
\text { chromosome }\end{array}$ & $\begin{array}{l}\text { Distured } \\
\text { spindle }\end{array}$ & $\begin{array}{l}\text { Anaphase } \\
\text { bridges }\end{array}$ & $\begin{array}{l}\text { Chromosome } \\
\text { fragment }\end{array}$ & $\begin{array}{l}\text { Chromosome } \\
\text { bridge }\end{array}$ & $\begin{array}{l}\text { Laggard } \\
\text { chromosome }\end{array}$ & Others & \\
\hline \multicolumn{11}{|l|}{ Control } \\
\hline (Tap Water) & 34 & 60 & - & - & - & - & - & - & - & - \\
\hline 5 & 69 & 47 & 3 & 3 & 1 & - & - & & 2 & 9 \\
\hline 10 & 66 & 32 & 2 & 8 & 1 & 2 & - & - & - & 13 \\
\hline 25 & 35 & 30 & 1 & - & 2 & - & 13 & 2 & 3 & 21 \\
\hline 50 & 45 & 15 & 1 & 2 & 1 & - & 18 & 1 & 1 & 24 \\
\hline 100 & 38 & 25 & 7 & 8 & - & - & 10 & 5 & 4 & 34 \\
\hline $\begin{array}{l}\text { TOTAL } \\
\text { \% Total }\end{array}$ & 385 & 255 & 11 & 18 & 4 & 2 & 41 & 8 & 10 & 101 \\
\hline Aberration & & & 10.98 & 17.82 & 3.96 & 1.98 & 40.59 & 7.92 & 9.90 & \\
\hline
\end{tabular}


Table 4. Mitotic inhibition induced by different concentration of e-waste leachate sample on the root tip of $A$. cepa.

\begin{tabular}{llll}
\hline Concentration (\%) & No. of cells scored & Mitotic index & Mitotic inhibition \\
\hline Control (Tap water) & 4000 & $\mathbf{1 4 . 1 3}$ & - \\
5 & 4000 & $\mathbf{9 . 7 3}$ & $31.14^{*}$ \\
10 & 4000 & $\mathbf{7 . 1 3}$ & $49.54^{*}$ \\
25 & 4000 & $\mathbf{6 . 5 8}$ & $53.43 *$ \\
50 & 4000 & $\mathbf{5 . 6 0}$ & $60.37^{*}$ \\
100 & 4000 & $\mathbf{5 . 0 5}$ & $64.26^{*}$ \\
\hline
\end{tabular}

Notes: * Values significant at $P<0.05$.

\subsection{Chromosomal Aberration in A. cepa}

The effect of the e-waste leachate on cell division and chromosome behaviour of Allium cepa root tips cells are shown in Tables 3 and 4. Mitotic index (MI) was concentration dependent recording the highest value of 14.13 at control and decreasing in the following order $9.73>7.13>6.58>5.60>5.05$ at 5, 10, 25, 50 and 100\% leachate concentration, respectively, in Table 4. Mitotic inhibition thus was inversely proportional to MI, increasing from 5-100\% concentration with the least mitotic index and highest mitotic inhibition recorded at $100 \%$ concentration in Table 4 . The MI and percentage mitotic inhibition varied statistically from the control values at $P<0.05$ Table 3 . There was no chromosomal aberration in the control, however, chromosomal aberrations were induced at all concentrations of the e-waste leachate and were statistically significant at $P<0.05$ with increasing concentration of the leachate. The types of chromosomal aberrations induced by the leachates include disturbed spindle and fragmentation, sticky chromosome, chromosome bridge and chromosome lags in Table 4 and Figure 4.

\section{Discussion}

The physicochemical parameters analysed for tap water used as a control in the present study compared well with stipulated standards by $[13,17]$. However, the metals analysed in the e-waste leachate were higher than stipulated limits by $[13,17]$ and higher than reported by other literature on e-waste [8]. Compared to the present study, electronic waste has been reported to leach high levels of metals into the environment. In Agbogbloshie and Koforidua, two major e-waste recycling sites in Ghana, the concentrations of copper, lead, zinc and tin in soil were found to be in the magnitude of over one hundred times of typical background levels. In particular, the concentrations of lead in soil and ash samples collected in these sites were found to be as high as $5510 \mathrm{mg} / \mathrm{kg}$ dry weight [19]. At the present study area, e-waste was simply dumped in municipal solid waste streams without considerations for its potential harm to the environment and human health $[6,11]$. There have been attempts by informal recyclers to retrieve useful parts of the e-waste and, in most cases, burn whatever is not needed [11]. Either way, rainfall and storm water may leach contaminants such as trace metals from the e-waste into surface and ground waters and may result to ecological and human health disasters including irreversible changes at the genetic level as proven by the cytotoxicity test in the present study.

The burning of the e-waste is not a good option as either exposure to lead fumes or dust is known to cause multiple disorders, including neurological, cardiovascular and gastrointestinal diseases [20], 
exposure to cadmium fumes or dust leads to malfunctioning of the kidneys [21] and the respiratory system [22], and possibly lung cancer [23]. Either inhaled or swallowed through the food chain, the metals are capable of eliciting the same results as observed in the present study. Similar concerns have also been reported in Nigeria, where open incineration of cables and electronic components is a common practice to recover copper and other precious metals without any proper and safe working conditions [5,24]. As a result of these activities, toxic chemicals such as lead, mercury, arsenic, cadmium, selenium, chromium, barium, nickel, cobalt, silver etc., persistent organic pollutants (POPs e.g., dioxins and furans), polybrominated diphenyl ethers (PBDEs), polychlorinated bisphenyls (PCBs), polyvinyl chlorides (PVCs) and polycyclic aromatic hydrocarbons (PAHs) are released into the surrounding air, soil, plants and surface waters. Leaching of e-wastes from informal dumpsites can contaminate groundwater sources, thereby exposing humans and animals to serious health azards [7,8].

Physico-chemical properties were in excess quantities in the samples tested in our study compared to control and maximum levels by [17] and may have been responsible for the effects observed. For example, it has been reported that biological damage effects from the compound in a complex mixture may be enhanced by extreme $\mathrm{pH}$ values of the sample [25]. The $\mathrm{pH}$ of 6.17 obtained from the raw leachate sample (Table 1) in this study may have influenced the toxicity of the root growth of $A$. cepa. Nickel, which has been found to be highly toxic, was also analysed in the sample at levels much higher than in control and maximum permissible limits for leachate discharged by regulatory bodies [17]. Nickel is known to penetrate cells rapidly and causes osmotic lyses of cells resulting in cell death [26].

The percentage root growth at the five concentrations $(5 \%, 10 \%, 25 \% 50 \%, 100 \%)$ tested was lower than in the control, indicating root growth inhibition by the e-waste sample at all concentrations tested and root growth inhibition was strictly concentration-dependent as also reported by [8] when they tested e-waste leachate from the Lagos electronic market on A. cepa. The EC50 value obtained (35.0\%) provided information on general toxicity with an insight into the potential toxicity of e-waste leachate entering the environment at the market in Iloabuchi Street, Rivers State, Nigeria. Bakare et al. [8] reported an $\mathrm{EC}_{50}$ of $34.1 \%$ for e-waste leachate from Lagos State, closely agreeing with that obtained in the present study. With strict adherence to the optimal level of environmental conditions necessary in the Allium cepa test procedure, the toxic effect observed at the various concentrations of e-waste leachate sample in our study is considered likely biological hazards in any living system. The induction of root malformations in A. cepa has been shown to be useful signs of toxicity in previous studies $[8,10]$. Compared to the onion bulbs grown in the control, the root tips of onion bulbs grown in the e-waste leachate in the present study were characterized by twists and crotchet roots (roots bent upwards resembling hooks) and C-tumor (roots with abnormal swellings) as reported also by [8].

Results of $A$. серa root growth obtained in this study are similar to those reported in several other investigations of the toxicity of complex mixtures to A. cepa $[10,27]$. Electronic waste water is an example of complex mixtures whose biological effects may be difficult to predict [25]. However, results obtained for the Allium cepa test usually provide information into the likely toxicity and environmental risk of such mixtures [25]. The closest results to the present study is that of [8], which reported the potential cytogenotoxicity of e-waste leachate and contaminated well water samples obtained from Alaba International Electronic Market in Lagos, Nigeria, using induction of chromosome and root growth anomalies in Allium cepa. 
The information that determines the characteristics of a cell or organism is contained in the genetic material called DNA. The genetic information is passed from one generation to the next by precise duplication of the strands of DNA and its equal distribution prior to cell division. When the sequence or number is altered and becomes heritable, mutation occurs. It may be point mutation, whereby only short regions of the sequence is altered (e.g., the substitution of a base for another, deletion or addition of one or several bases), or it may be chromosomal mutations or aberrations affecting larger pieces of the chromosome or the total chromosome number of the cells. Positive results of mutagenicity obtained in short term bioassays such as Ames tests, human lymphocytes, Chinese hamsters, Allium cepa tests, etc. can be used to predict the chemical potential to cause cancer.

In our study, the ability of the e-waste sample to produce breaks and induce irreparable damage to the chromosome of the test system, A. cepa is considered for the samples potential to produce mutations in the test system. The clastogenic effect, which results in the chromosomal aberrations, is a good indication of the general toxicity of the tested leachate sample, indicating that it contains some chemicals known to obstruct the spindle action to give rise to mitotic disturbances generating cytological effects such as aneuploidy or polyploidy with significant genetic effects, an opinion shared by previous researchers $[8,10]$. This occurred as a result of chromosome segregation errors caused by the disturbances of spindle action. Chromosome aberration or cytological aberrations in plants cells serve as excellent monitoring systems for the detection of environmental chemicals that may pose genetic hazards $[8,10]$. In addition, A. cepa roots are known to possess enzymes capable of activating pro mutagens, making their detection easier [10,27].

The E-waste water sample tested in the present study induced chromosome abnormalities and also lowered mitotic index as compared to the control. Sample was found to be mutagenic, inducing various types of chromosome abnormalities in A. cepa. Induction of both chromosomal aberrations and mitotic inhibition were found to be statistically significant at $P<0.05$ and induction increased with increased concentration for both effects. Mitotic index was lower than in control at all concentrations of e-waste leachate tested. There was a high correlation between total chromosome aberration and mitotic inhibition at statistically significant levels $(P<0.05)$. This may suggest that induction of mitotic inhibition can give rise to chromosome abnormalities and vice versa, making it possible to use a regression model to predict the effect of one on the other in a specific or consistent sample.

Six types of aberrant cells induced by e-waste leachate in A. cepa were observed which included sticky chromosomes, disturbed spindle, chromosome laggards, chromosome breaks, Anaphase bride, chromosome fragments and chromosome bridge. Chromosome stickiness may arise from improper folding of the chromosomes and, as a result, there is intermingling of fibres, and the chromosomes become attached to each other by means of sub-chromated bridges and indicate highly toxic, usually not reversible effects probably leading to cell death [25]. The formation of sticky chromosome leading to cell death may impede the growth of A. cepa; this gives information about the general toxicity of the sample. Spindle disturbances is an effect characterised by the spindle action resulting in disoriented centromes heading in multiple direction or poles in the cell. Similar chromosomal aberrations were reported by [8] in A. cepa cells treated with e-waste leachate from Alaba International market, Lagos. Generally, our results showed that cytotoxicological aberrations occurred in A. cepa root tips cells when treated with e-waste leachate samples from Iloabuchi electronic market, Port Harcourt, Rivers State, Nigeria and suggest the e-waste samples were genotoxic at the chromosome level, closely agreeing with 
the findings of [8]. Earlier, [28] reported DNA fragmentation and cell death by apoptosis in mouse fibroblasts indicating that apoptic pathways may be a mechanism of e-waste induced cytogenotoxicity.

There was a high correlation $(\mathrm{R}=0.953)$ between the microscopic observations and macroscopic effects. The mitotic inhibition may result in reduced cell multiplication and growth, and clastogenic effects may result in cell death. All these would invariably result in root growth inhibition observed macroscopically as shown in Figure $3[8,10]$.

\section{Conclusions}

Results of our study suggest that anomalies in cell division processes and chromosome aberration induced in the Allium cepa root meristem could be a result of the interaction of heavy metals from the electronic waste leachate. Since the mechanism of DNA toxicity in all biological systems may be similar, care must be taken as clastogenic effects elicited by e-waste leachate in the cells of A. cepa may spell doom for all living things exposed to the leachate at the study site. Electronic waste has become a similar challenge to those posed by other domestic solid wastes but also presents opportunities for recovery, reuse and recycling of its important components that are generally discarded with proven environmental and human health hazards. Adequate legislation can create opportunities for former e-waste recycling programmes integrating the recyclers for improved environmental and health performance.

\section{Author Contributions}

Bolaji Babatunde conceived the research, Felicity Anabuike carried out the practical work supervised by Bolaji Babatunde, and both analysed the data. Felicity Anubuike wrote the manuscript, and Bolaji Babatunde reviewed and adapted the manuscript to fit the style of the journal.

\section{Conflicts of Interest}

The authors declare no conflicts of interest.

\section{References}

1. Robinson, B.H. E-waste: An assessment of global production and environmental impacts. Sci. Total Environ. 2009, 408, 183-191.

2. Sthiannopkao, S.; Wong, M.H. Handling e-waste in developed and developing countries: Initiatives, practices, and consequences. Sci. Total Environ. 2013, 463-464, 1147-1153.

3. Arora, R. Best Practices for E-Waste Management in Developing Nations. GTZ-ASEM: New Delhi, India, 2008.

4. Nnorom, I.C.; Osibanjo, O. Electronic waste (e-waste): Material flows and management practices in Nigeria. Waste Manag. 2008, 28, 1472-1479.

5. Manhart, A.; Osibanjo, O.; Aderinto, A.; Prakash, S. Informal E-Waste Management in Lagos, Nigeria-Socio-Economic Impacts and Feasibility of International Recycling Co-Operations; Final Report of Component 3 of the UNEP SBC E-waste Africa Project; Öko-Institut e.V.: Freiburg, Germany, 2011. 
6. Orisakwe, O.E. Environmental pollution and blood lead levels in Nigeria: Who is unexposed? Int. J. Occup. Environ. Health. 2009, 15, 315-317.

7. Alabi, O.A.; Bakare, A.A. Genotoxicity and mutagenicity of electronic waste leachates using animal bioassays. Toxicol. Environ. Chem. 2011, 93, 1073-1088.

8. Bakare, A.A.; Okunola, A.; Alabi, A.M.; Gbadebo, I.O.; Alimba, C.G. In vivo cytogenotoxicity and oxidative stress induced by electronic waste leachate and contaminated well water. Challenges 2013, 4, 169-187.

9. Rank, J.; Nielsen, M.H. Allium cepa anaphase-telophase root tip chromosome aberration assay on N-methyl-N-nitrosourea, maleic hydrazide, sodium azide, and ethyl methanesulfonate. Mutat. Res. 1997, 390, 121-127.

10. Babatunde, B.B.; Bakare, A.A. Genotoxicity screening of wastewaters from Agbara industrial estate, Nigeria evaluated with the Allium test. Pollut. Res. 2006, 25, 227-234.

11. Konya, R.S.; Babatunde, B.B.; Iniefe, D. Assessment of e-waste statue in port Harcourt and its environs. Environ. Sci. 2013, 3, 45-66.

12. APHA/AWWA/WEF. Standard Methods for the Examination of Water and Waste Water, 20th ed.; American Public Health Association/American Water Works Association/Water Environment Federation: Washington, DC, USA, 1998.

13. United States Environmental Protection Agency (USEPA). National recommended water quality criteria-Correction: EPA 822/Z-99-001; USEPA: Washington, DC, USA, 1999.

14. Bakare, A.A.; Lateef, A.; Amuda, O.S.; Afolabi, R.O. The aquatic toxicity and characterization of chemical and microbiological constituents of water samples from Oba River, Odo-Oba, Nigeria. Asian J. Microbiol. Biotechnol. Environ. Sci. 2003, 5, 11-17.

15. Fiskesjo, G. Allium test for screening chemicals: Evaluation of cytologic parameters. In Plants for Environmental Studies; Wang, W., Gorsuch, J.W., Hughes, J.S., Eds.; CRC Lewis Publishers: Boca Raton, NY, USA, 1997; pp. 308-333.

16. ASTM. Standard Practice for Conducting Early Seedling Growth Tests 1, American Society for Testing and Material Designation E 1598-94; ASTM: Washington, DC, USA, 1994; pp. 1493-1499.

17. Federal Environmental Protection Agency (FEPA). S1.8 National Environmental Protection (Leachate Limitations) Regulations; FEPA: Washington, DC, USA, 1991.

18. World Health Organisation (WHO). Guideline for Drinking Water Quality—Recommendations 2; World Health Organisation: Geneva, Switzerland, 1996.

19. Brigden, K.; Labunska, I.; Santillo, D.; Johnston, P. Chemical contamination at e-waste recycling and disposal sites in Accra and Korforidua, Ghana; Greenpeace International: Amsterdam, The Netherland, 2008.

20. Haefliger, P.; Mathieu-Nolf, M.; Lociciro, S.; Ndiaye, C.; Coly, M.; Diouf, A.; Faye, A.L.; Sow, A.; Tempowski, J.; Pronczuk, J.; Filipe Junior, A.P.; Bertollini, R.; Neira, M. Mass lead intoxication from informal used lead-acid battery recycling in Dakar, Senegal. Environ. Health Perspect. 2009, 117, 1535-1540.

21. Hellstrom, L.; Elinder, C.G.; Dahlberg, B.; Lundberg, M.; Jarup, L.; Persson, B.; Axelson, O. Cadmium exposure and end-stage renal disease. Am. J. Kidney Dis. 2001, 38, 1001-1008. 
22. WHO. Report on Inventorization of E-Waste in Two Cities in Andhra Pradesh and Karnataka (Hyderabad And Bangalore); WHO: Geneva, Switzerland, 2010.

23. National Toxicology Program, Public Health Service, U.S. Department of Health and Human Services (DHHS). Report on Carcinogens, 11th ed.; DHHS: Research Triangle Park, NC, USA, 2008.

24. Osibanjo, O.; Nnorom, I.O.; Bakare, A.A.; Alabi, O.A. Environmental and public health consequences of adopting crude recovery techniques in e-waste management in developing countries: An emerging global crisis. In Advances in Environmental Research; Daniels, J.A., Ed.; Nova Science Publishers Inc.: Hauppauge, NY, USA, 2012; Vol. 171.

25. Fiskesjo, G. The Allium test as a standard in environmental monitoring. Hereditas 1985, 102, 99-112.

26. Ferrari, B.; Marcos, C.; Radetski, A.-M.V.; Ferard, J.-F. Ecotoxicological assessment of solid waste: A combined liquid- and solid-phase testing approach using a battery of bioassays and biomarkers. Environ. Toxicol. Chem. 1999, 18, 1195-1202.

27. Bakare, A.A.; Wale-Adeyemo, A.R. The mutagenic and cytotoxic effects of leacheates from domestic solid wastes and Aba-Eku landfill, Nigeria on Allium cepa. Nat. Environ. Pollut. Technol. 2004, 3, 455-462.

28. Alabi, O.A.; Bakare, A.A.; Filippin-Monteiro, F.B.; Sierra, J.A.; Creczynski-Pasa, T.B. Electronic waste leachate-mediated DNA fragmentation and cell death by apoptosis in mouse fibroblast (NIH/3T3) cell line. Ecotoxicol. Environ. Saf. 2013, 94, 87-93.

(C) 2015 by the authors; licensee MDPI, Basel, Switzerland. This article is an open access article distributed under the terms and conditions of the Creative Commons Attribution license (http://creativecommons.org/licenses/by/4.0/). 